\title{
Store Brand Equity: An Explorative Study
}

\author{
Guido Cristini ${ }^{1}$, Cristina Zerbini ${ }^{1} \&$ Elisa Martini ${ }^{1}$ \\ ${ }^{1}$ Department of Economics and Management, University of Parma, Italy \\ Correspondence: Cristina Zerbini, Department of Economics and Management, University of Parma, Italy. \\ E-mail: cristina.zerbini@unipr.it
}

Received: July 27, 2018

doi:10.5539/ijbm.v13n11p122
Accepted: September 26, 2018

Online Published: October 12, 2018

\begin{abstract}
In regards to food consumption in Italy, consumers demonstrate a growing appreciation for Store Brands in their various forms: premium, mainstream and value. While retailing literature has largely been focused on the determinants behind the Store Brand's success, little attention has been paid to a specific model able to describe and explain the main factors behind the creation of retail brand equity. Drawing on the literature that has analyzed the success of the Store Brand, this paper aims to assess the Italian consumer's perception of the Store Brand. It is particularly interesting to study the consumers' comparative evaluations between the two types of Store Brand segments: mainstream and premium. The variables which characterize a Store Brand's Identity and those which enable it to offer a credible alternative to the leading industrial brands will be the focus of the study. They include: price advantage, perceived quality, level of innovation, ethics and sustainability. Data were collected from a quantitative survey based on a structured questionnaire. The final sample group was made up of approximately 600 Store Brand consumers loyal to the same retailer. Looking at the two Store Brand segments analyzed, results demonstrate that the consumers' opinions differ in regards to price advantage, while they remain relatively uniform in regards to the other factors. These results lead to important managerial implications as they highlight how important it is to qualify a Store Brand's distinctive factors, implement communication policies and to understand the final consumers' expectations in order to increase its overall value.
\end{abstract}

Keywords: assortment, branding, consumer perception, retail, retail brand equity, store brand

\section{Introduction}

In marketing literature, the scientific and managerial debate over the topics of branding and the determinants that enable a brand to create and defend value is alive and well. Over the past twenty-five years, a systematic and meaningful contribution to this subject has been made by Aaker (1991, 1996, 2004), and by Aaker and Joachimsthaler (2000) who, in several articles, have demonstrated how a brand represents a fundamental company asset, able to qualify and identify value generated by a product or service.

Another relevant contribution to branding studies has been made by Keller $(1993,1996,1998,2000,2001)$ who, in the framework of a broad systematic design, has developed the Customer Based Brand Equity Model (CBBE). In this model, a pyramid scheme is used to show which the factors are able to affect brand creation and its constant relationship with the final consumer.

In the current economic context, and in light of the evolution of households' buying patterns in grocery markets, the Store Brand, offered and provided by retailers as a valid alternative to well-known industrial brands, has become increasingly important to consumers. In fact, due to its growing success in the majority of developed markets (Western Europe and North America), it is particularly interesting to study whether (and how) Keller's brand equity model (Keller, 1998) can be applied (or adapted) to the SB and which are the "specific" factors that could have a greater impact on the creation of a loyal relationship with the final consumer.

It should be pointed out, that the adaptation of the generalist model to the SB has rarely been studied in marketing literature and that the few contributions on the topic are numerically limited. Amongst these, Jara and Cliquet (2012), who applied Keller's model to the SB context, tested for the presence of similarities between general brand equity and retail brand equity in terms of brand awareness, brand image and brand identity, studying those variables that are not only accepted by academics but also by business managers. In this framework, the benefit of studying the SB identity profile and how, over time, the degree of importance of 
certain factors (i.e. price advantage) has changed is highlighted.

In fact, as some retailing literature states, the SB was initially introduced to offer a lower price alternative to the leading (or national) brands (Myers, 1967; Coe, 1971; Bettman, 1974). Then, in order to fight hard discount development in the majority of European countries, the SB was able to increase its value by becoming a generic brand, defined as a "no frills" offer, mainly characterized by its price advantage.

Later on, several retailers started to include "me-too" products (Laaksonen \& Reynolds, 1994) in their assortment, citing a double objective: on one hand, to guarantee a greater margin, while on the other, to increase their market power over the leading brands (Narasimhan \& Wilcox, 1998). Additionally, in terms of mainstream SBs (a SB known by the same brand name as its distributor), retailers aimed at increasing consumer loyalty by offering quality products and developing categories in which their competitors had not yet entered (Steenkamp \& Dekimpe, 1997).

In this historical context, it is useful to call attention to the growing segmentation of SBs into premium segments, aimed at specific demand clusters. This is a direct result of the change in the consumer shopping and consumption behavior, of increasing consumer interest in obtaining high quality brands and products at advantageous prices (Huang \& Huddleston, 2009).

Indeed, the SB premium segment permits retailers to offer products known for their unique factors through an improvement strategy focused on different elements, such as innovation, sustainability and ethics. These are known as the representative variables relevant to SB purchase and consumption decisions made in the most developed countries. For this reason, it is of great interest to understand whether the SB can be interpreted according to the perspective and market segmentations indicated by Keller. Specifically, it is useful to verify whether the consumer perception changes when he/she wants to buy a "mainstream" SB (the brand that has, over time, represented the most advantageous alternative to the corresponding industrial brand in the "mainstay" categories) compared to a "premium" one (which could also be included in qualified, innovative and niche categories).

Due to an absence of published research on retail brand equity measurements, this study aims to fill the gap by analyzing the Italian consumer's assessment in terms of these two different SB types in reference to a single retailer. More specifically, in order to identify why an SB is chosen in the Italian market, the consumer's perception of the SB's key factors (price advantage, perceived quality, level of innovation, ethics and sustainability) (Cristini \& Zerbini, 2017) will be investigated.

The present work is structured as follows: in the second paragraph, a summary of the main literature on brand equity is provided, using the model of value analysis advanced by Keller (1993) as the key to understanding. The goal here is to evaluate whether it can also be applied to a specific brand model, the SB. To achieve this, and in keeping with recent retailing literature, the key factors known to characterize the SB were selected, thus allowing for an assessment of their value through a measurement of the final consumers' evaluations. Therefore, the paragraph concludes with the formulation of the research hypotheses.

The methodology used is presented in the third paragraph. It focuses on a quantitative survey that was carried out on a sample of consumers who regularly purchase SB products from their preferred retailer.

In the fourth paragraph, the primary findings are reported and certain managerial implications are discussed; they provide indications on two central aspects of SB enhancement. On one hand, the importance of understanding the reasons behind the consumers' assessments in order to verify whether the communication processes have actually managed to transmit the intended message. On the other hand, the data collected may orientate the management towards deciding to implement new strategies to improve the SB with reference to those distinctive factors that remain, in part, unsatisfactory to the final consumer.

Finally, in the last paragraph, the main limitations of the work and indications for future research on relevant aspects which have not been examined in the present study are reported.

\section{Literature Review and Research Hypotheses}

Based on the retailers' assortments, characterized by an increasing proliferation of products, consumer choice has become less tied to the physical and functional attributes of a product (basic requirements), and increasingly on the immaterial attributes of the brand (mainly related to values that represent its personality). If this is the prevailing trend, then companies will need to implement strategies focused on strengthening brand reputation factors since it is critical to their competitive advantage.

Given this, it is therefore advisable to refer to the CBBE model developed by Keller (1993) (Figure 1), which, 
through a simplified scheme called "pyramid", is able to show the key required elements for building a strong brand. In particular, the Keller focuses his attention on the consumers' psychological dimensions and on the phenomena that influence their perception of the brand, the main tool able to improve the trust relationship. Moreover, this model is able to identify two different components of the brand: the identifying and the perceptual-trust components. One can observe, through the interaction of these aspects, how the model is therefore able to identify the factors that define brand awareness: brand identity and brandl image.

With respect to brand value generation, two predominant lines of thought emerge from the literature: the first applies a purely financial approach, while the second relies more heavily on factors that foster share growth and brand profitability in relation to the consumer expectation and perception system (Christodoulides, De Chernatony, Furrer, Shiu \& Abimbola, 2006). In terms of the financial approach, performance indicators are first represented by sales and profit, and therefore refer increasingly to short-term indicators (Mizik \& Jacobson, 2008).

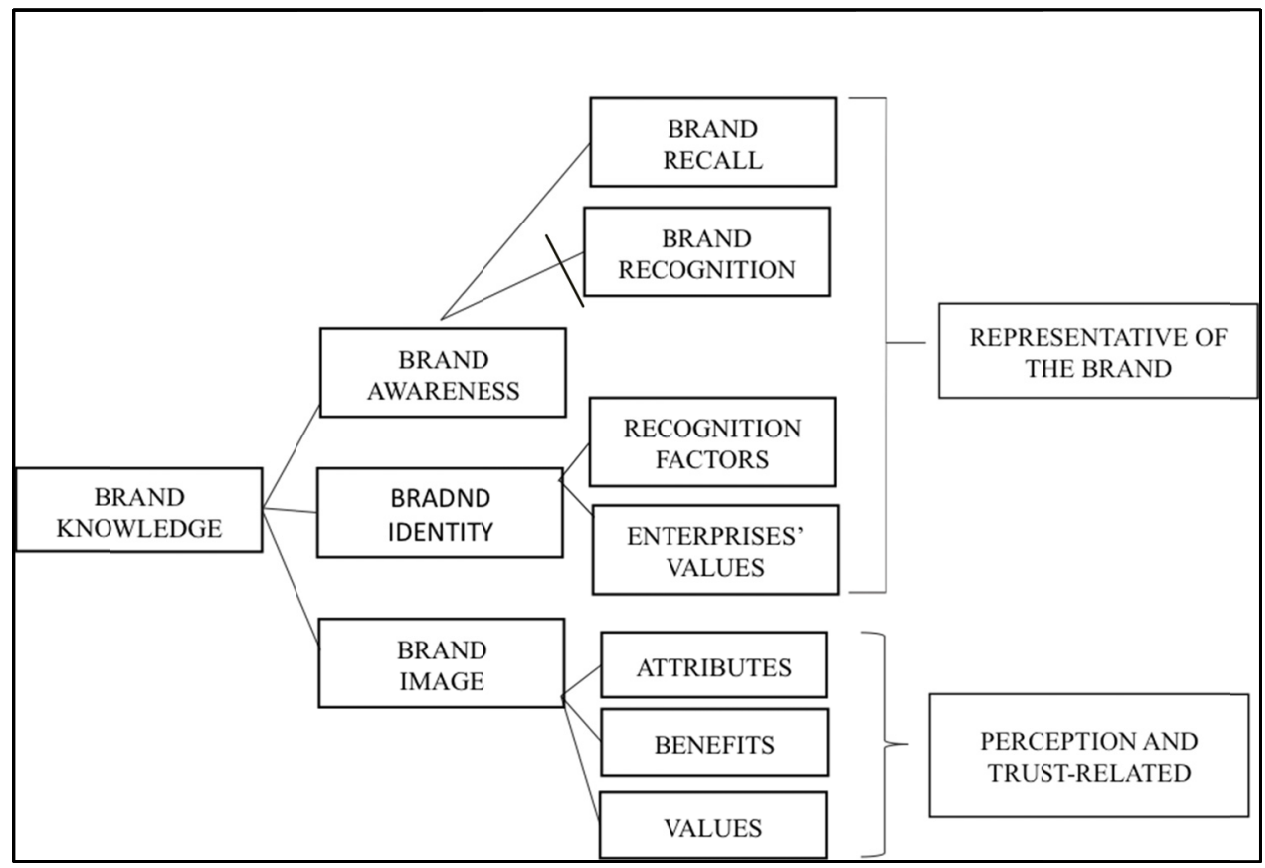

Figure 1. Brand component in Keller's model

Source: Adapted from Keller (1993), Busacca (2000).

Several scholars argue that brand equity can have positive effects on brand preference, purchase intention (Cobb-Walgren, Ruble \& Donthu, 1995; van Osselaer \& Alba, 2000) and brands alliances (Rao \& Rueckert, 1994).

The three previously mentioned constructs (brand awareness, brand identity and brand image) are recognized, by the great majority of academics, as key components of the CBBE: Table 1 shows the main research carried out on the topic, as summarized by Christodoulides (2010).

In the literature, brand equity is defined as an asset focused on the relationship with the market (Hunt, 1997; Srivastava, Shervani \& Fahey, 1998; Srivastava, Fahey \& Christensen, 2001). The references in Table 1 show how attention has been focused on the relationship with the shopper, to whom perceived quality, the benefits linked to the uniqueness of the offer, trust and clarity represent the critical success factors.

Other scholars argue that brand value is fueled by the information economy (Erdem \& Swait, 1998) and that the brand represents a distinctive signal to the final consumer. The shopper can use it as a way to connect the product to the company's past behaviors. Furthermore, the authors demonstrate that the higher the brand value, the lower the perceived risk and the costs related to researching additional information, all to the customer's advantage. Therefore, it is also interesting to understand whether it is possible to apply the concept of brand equity to the SB and the grocery distribution sector, or if, instead, some adaptations are needed. It should be noted that the contributions on this subject are rather limited, since most literature has studied the SB in relation to the leading 
brand; that is by choosing a comparative method within the product category.

From our perspective, we believe that distribution and its branding models can also adopt the main factors from the aforementioned model in regards to brand awareness, brand identity and brand image (Aaker, 1997). As known, the first one refers to a consumer's ability to recall or recognize a certain brand. The second factor refers to a set of specific characteristics that can be attributed to the brand, while the third one pertains to a set of meanings associated with the brand. But given the nature of the SB, which represents a key element of a distributor's service offer in that it's critical to acquiring and retaining the final consumer (Berry, 1986), an adaptive model might be needed. Given this, an SB should not only be linked to product offer but must also take into account the bidirectional link it has with "its" retailer.

Literature has repeatedly stressed that point of sale influences the image of the retailer brand and vice versa (Ailawadi \& Keller, 2004; Burt \& Mavrommatis, 2006; Collins-Dodd \& Lindley, 2003; Grewal, Krishnan, Baker \& Borin, 1998; Kozinets, Sherry, DeBerry-Spence, Duhachek, Nuttavuthisit \& Storm 2002; Richardson, 1997; Martín Gutiérrez, 2006). In some studies, it has been shown how retail brand equity results from both the level of perception of the services offered (Burt \& Sparks, 2002) and from corporate dimensions formed by values and symbols typical of the chain (Ambroise, Ferrandi, Merunka \& Valette-Florence, 2003). According to Jara and Cliquet (2012), retail brand equity benefits can be driven by different sources: the offline shopping experience, the chain's personality - as displayed over time, the founding values, and institutional actions which are able to influence the shopper's response in terms of brand choice and intention to buy.

Table 1. Comparative framework of the CBBE studies (Christodoulides, 2010)

\begin{tabular}{|c|c|}
\hline Authors & CBBE Dimensions \\
\hline \multirow{4}{*}{ Aaker $(1991,1996)$} & brand awareness \\
\hline & brand associations \\
\hline & perceived quality \\
\hline & brand loyalty \\
\hline \multirow{2}{*}{ Blackston (1992) } & brand relationship \\
\hline & (trust, customer satisfaction with the brand) \\
\hline \multirow{2}{*}{ Keller (1993) } & brand knowledge \\
\hline & (brand awareness, brand associations) \\
\hline \multirow{3}{*}{ Sharp (1996) } & company/brand awareness \\
\hline & brand image \\
\hline & relationships with customers/existing customer franchise \\
\hline \multirow{2}{*}{ Berry (2000) } & brand awareness \\
\hline & brand meaning \\
\hline \multirow{5}{*}{ Burmann et al. (2009) } & brand benefit clarity \\
\hline & perceived brand quality \\
\hline & brand benefit uniqueness \\
\hline & brand sympathy \\
\hline & brand trust \\
\hline
\end{tabular}

Given this perspective, the findings of Jara and Cliquet (2012) should also be considered. They claim that retail brand equity is also derived from the benefits of a shopper's experience in a point of sales, as well as the personality the chain displays over time, through the values they promote and the institutional actions they put into place

In particular, in regards to retail brand awareness and retail brand image, the two authors identified the main dimensions to investigate, those which can influence the response of the shopper in terms of brand choice and intention to buy.

In this context, brand image has been broken down into five dimensions: perceived quality, price image, brand and retailer personality, brand service and store service. The results of the study show that only store service is unable to have a significant influence over the consumer's response.

Since some of the dimensions in Keller's model have been tested and validated in the distribution context, it is therefore possible to refer to a (retail) brand equity, based on partial indicators such as brand awareness and perceived quality, that is able to influence the behavior of the final consumer. On the contrary, price does not 
seem to represent a factor contributing to the development of a long-term relationship between retailer and consumer (Figure 2). Moreover, a certain degree of importance must be attributed to a mainstream SB's personality, where distinctive values and principles contribute to the creation of positive associations in the consumer's mind, encouraging trustful behavior.

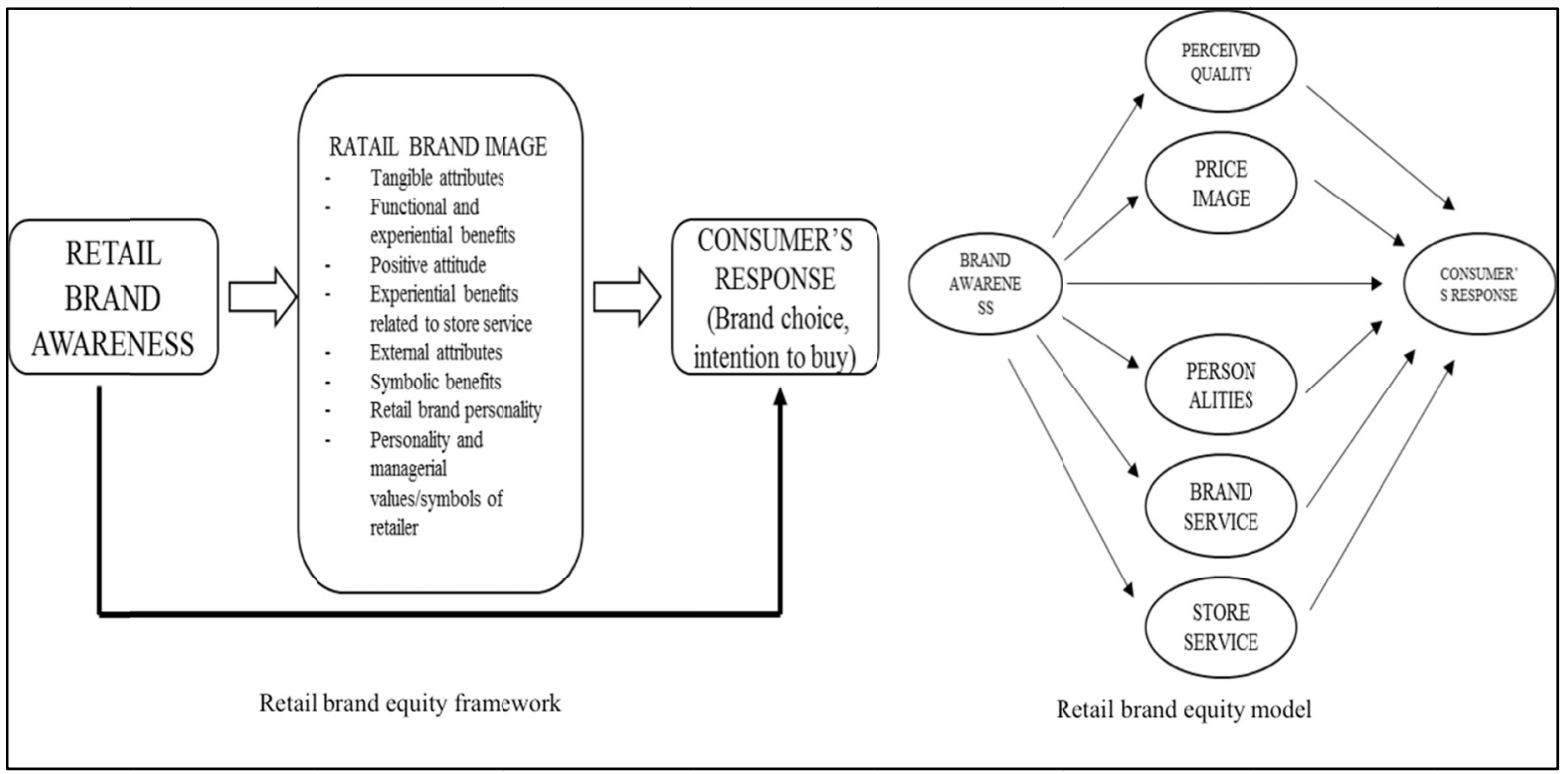

Figure 2. The framework of the brand equity related to the retail context

Source: Adapted from Jara and Cliquet, 2012.

Due to the changes in the consumer buying process and consumption behavior that are based on the growing demand for products that can meet requests for convenience, quality, innovation, variety, sustainability and ethics, it is clear that the role of the SB has greatly changed over time. It is moving closer and closer to a position of brand values guarantor that has generally been attributed to the leading brands. In fact, when retailers manage these dimensions they are better able to influence the associations that consumers create in their minds, initially attributable to brand image and, subsequently, to the construction of a brand awareness.

As highlighted by Jara and Cliquet (2012), given that brand awareness directly affects consumer behavior even in the distribution context, retailers should closely monitor those factors that characterize both the retailer and the $\mathrm{SB}$ in order to foster the creation of certain associations in the mind of the shopper.

Therefore, it is worth investigating the "signaling" factors of an SB (from the consumer's point of view). Additionally, it is important to understand whether, in light of the changes taking place in terms of expectations and values, the signaling factors of the past, such as price advantage and quality, still represent the main drivers behind SB choice or if, on the contrary, there are other elements that better represent an SB's identity.

As we already know, price advantage has always been the main factor behind a consumer's choice to buy an SB. This is the result of past strategies that were aimed at providing products characterized by an acceptable level of quality and at a much lower price in comparison to industrial brands (Wileman \& Jary, 1997; Burt \& Davis, 1999).

However, as seen in various studies, this is no longer the only motivating factor behind a consumer's decision, currently, he/she wishes to be reassured about other relevant SB elements as well. This shift in perspective (Verhoef. Nijssen \& Sloot, 2002) also seems to have been the basis for development of different SB variants over the years. An example of this would be premium segment which is known for other factors such as quality. In fact, one only needs to think as far as to the recovery and protection of original food tradlitions, the reemergence of a certain recipes, the selection of raw materials or products coming from specific territories, to find examples of those factors which identify an SB and enable it to become an ambassador of absolute quality.

Due to larger investments made by the chains in terms of attention to the quality of raw materials, the selection of new recipes, the vertical control of supply chains etc., SB products have continued to acquire a better product quality reputation. This hypothesis has been discussed in several scientific works over the years. For example, 
Hoch and Banerji, 1993; Burton, Lichtenstein, Netemeyer \& Garretson, 1998; Kilian, Walsh \& Buxel, 2008; Walsh and Mitchell, 2010; and Erdem and Chang, 2012 have demonstrated how a great number of consumers consider quality to be one of the most important factors behind their choice.

It is important to underline how, while the mainstream segment of the SB has allowed retailers to offer both price advantage and increase the margins generated over the years, in today's complex market, where segmentation in consumer buying processes is growing, it is no longer possible. This is why retailers now have to focus on innovation in order to offer innovative value propositions, differentiating themselves by price range and consumer segments. In light of this change, many SBs have implemented an upgrading strategy, based on the other key factors considered critical to a purchase, out of which one of the primary elements is innovation.

In order to be innovative, or, in other words, to be able to offer products that fulfill new consumer needs, retailers have not only reduced the time in which their own products had a comparable level of innovation to industrial brands, but also, through the development of new segments (usually premium), they have been able to offer special products, often niche, with their own brand, closely tied to local food traditions.

In doing this, the SB becomes the platform through which retailers can offer products that the manufacturers are unable to because they come from, in part, artisanal products found only in certain territories and are therefore more difficult to sustain through marketing investments. In this way, the individual retailer has been able to provide a specific offer tied to a selection of local products, allowing it to be perceived as "innovative" when compared to the national market, generally controlled by medium-large sized national companies and interested in promoting products and brands to large user targets.

Here, the relationship with the suppliers is of great importance, as they must not only be able to guarantee high quality standards, but also suitable in terms of safety and capable of satisfying the specific requests of a limited, but demanding, consumer segment. (Note 1)

Moreover, the fact that people display an increasing interest in environmental issues means that a product's sustainability also plays fundamental role in a SB purchase. According to Rondinelli and Berry (2000), today's consumer recognizes the importance of sustainability as a strategy of environmental protection that applies not only to the location where the company operate, but also where the SB's suppliers are found. Therefore, communication becomes an important lever on which companies or retailers must pull to make sure their consumers know what actions they are taking in terms of sustainability. By using the right tools and the right strategy, the company or retailer has an excellent opportunity to educate and inform them.

The authors argue that "sustainability-based brand knowledge" enables a company to create a long-term relationship with the final consumer, creating value across the whole channel. In this sense, the literature highlights how a green brand image, green trust and green satisfaction can bring consumers to accept a premium price for products perceived as sustainable and natural (Gupta \& Kumar, 2013).

Additionally, growing social sensitivity explains the shopper's increasing attention to ethical behavior (Nielsen, 2008). Several authors (Gupta \& Sen, 2013; Irwin \& Naylor, 2009; Luchs, Naylor, Irwin \& Raghunathan, 2010; Bodur, Tofighi \& Grohmann, 2016) sustain that the ethical attributes sought by the shopper are tied into a growing sensitivity towards environmental protection, human rights, animal welfare and attention to the rights of workers demonstrated through actions that help prevent discrimination or the exploitation of child labor (Bodur, Gao \& Grohmann, 2014; Irwin \& Naylor, 2009). Other concepts which can make up part of the ethical dimension are the attention developing countries through the promotion of fair-trade agreements (Irwin \& Naylor, 2009) and the adoption of cause-related marketing projects in favor of charitable institutions and institutions (Varadarajan \& Menon, 1988).

In an experiment conducted by Bodur et al. (2016), the authors point out that a retailer's positive reputational level is a precondition for the success of products with explicit "ethical" connotations. Generally, retailers with a modest "social commitment" reputation are not able to ensure their success in "ethical" product segments and therefore, their SB is not offered in this segment.

Considering the conceptual framework described above, and in reference to the Italian distribution market, some authors (Cristini \& Zerbini, 2017) have recently studied the level of importance a consumer attributes to the main factors characterizing SBs in their purchasing decisions. In particular, several SB key dimensions were investigated, such as the level of price advantage, the perceived quality, the level of sustainability, the degree of innovation, and the supervision of those actions which ensure a retailer's ethical behavior. The results highlight that considerable attention is paid to the aforementioned factors, which in fact, serve as the basis for an SB purchasing decision. In other words, the once-declared "me too" positioning of an SB, based on the concept that 
a consumer would be offered a product at a lower price through a functional imitation of the industrial product, is no longer valid. The study demonstrates that the reason behind an SB purchase also depends on the new dimensions (not only price) that make up its identity and help garner the consumer's appreciation.

Therefore, it seems useful to understand whether there are significant differences in the perception of SB attributes, as expressed by shoppers who purchase both the mainstream SB and the premium SB (Table 2) from the same retailer. More specifically, this study aims to fill this knowledge gap by studying the Italian consumer's perception of the factors that characterize the SB in the main segment, "mainstream," -as well as in the "premium" one, through the formulation of the following two hypotheses:

H1: The evaluation made by shoppers regarding price advantage is higher for those who buy the mainstream SB compared to shoppers who buy the premium $S B$.

H2: The evaluation made in relation to (a) quality, (b) level of innovation, (c) sustainability and (d) ethics is lower for shoppers who buy the mainstream $S B$ when compared to shoppers who buy the premium $S B$.

Table 2. Factors that characterize the SB

\begin{tabular}{ll}
\hline Factors & References \\
\hline \multirow{4}{*}{ Quality } & Hoch and Banerji (1993) \\
& Burton et al. (1998) \\
& Kilian et al. (2008) \\
Price Advantage & Walsh and Mitchell (2010) \\
Innovation & Erdem and Chang (2012) \\
& Wileman and Jary, (1997) \\
Sustainability & Burt and Davis, (1999) \\
& Kumar and Steenkamp (2007) \\
& Rondinelli and Berry (2000) \\
Ethics & Gupta and Kumar (2013) \\
& Varadarajan and \\
& Menon (1988) \\
& Irwin e Naylor (2009) \\
& Luchs et al. (2010) \\
& Gupta e Sen (2013) \\
& Bodur et al. (2014), (2016) \\
\hline
\end{tabular}

\section{Methodology}

This study opted to focus on a specific retailer. In particular, it is the leading retailer in the Italian distribution market, characterized by both a high rate of SB penetration and the presence of a premium SB segment well-known to its customers since it has been offered as part of the assortment for several years' time. By choosing this chain for the field study, we were able to investigate the existence of differences in the consumer's evaluations between the mainstream and premium SBs.

The stated objectives of this paper were studied by means of a quantitative survey with a structured questionnaire, given to a sample of retail customers who claimed to purchase both mainstream and premium SB products.

The first part of the questionnaire contained socio-demographic queries. In the second part, questions were asked to measure the dependent variables, namely the dimensions that, according to the retail literature treated, characterize a SB: perceived quality, price advantage, level of innovation, ethics and sustainability. These dimensions were measured using the five-point Likert scale, each anchored by $1=$ disagree and $5=$ completely agree. Table 3 shows the items and their corresponding dimensions.

The sample was randomly divided into two groups: (a) mainstream group and (b) premium group. The questionnaire given to the two groups contained the same questions, but the respondents of Group (a) had to refer to the mainstream SB, while those of Group (b) to the premium SB.

A total of 569 complete questionnaires were collected: 316 for the mainstream group and 253 for the premium group. 
Statistical analyses were performed with the SPSS 24.0 statistical analysis software (SPSS Inc, Chicago, IL).

\subsection{Sample Characteristics}

The sample group surveyed consisted mainly of women (62\%), proving that they are the main purchasing managers in Italian families. The age of the respondents ranged from a minimum of 18 to a maximum of 86 years, with an average of 47.8 years.

The level of education of respondents appears quite high: just over half of the sample has graduated high school $(52.4 \%) ; 35.1 \%$ have a university or postgraduate degree; $2.8 \%$ left school at the end of elementary school, while $9.3 \%$ have a secondary school certificate. Only $0.4 \%$ have no educational qualifications.

The majority of the sample group has a job: $50.4 \%$ have contracts for an indefinite period and $9.3 \%$ for a fixed term; $6.7 \%$ are unemployed and $1.9 \%$ are looking for their first job. Housewives represent $13.9 \%$ and pensioners $13.4 \%$. The remaining part of the sample group is divided between students $(3.7 \%)$ and retirees $(0.7 \%)$.

The composition of the family nucleus varied: $10.2 \%$ of respondents are single, $3 \%$ live in a family of 5 or more members and the remainder in households consisting of 2 to 4 members. If the majority of the sample declare to have only one child (49.4\%) and $26.7 \%$ two children, the respondents who have 4 or more children are a minority (4.4\%).

Table 3. Questionnaire dimensions and items

\begin{tabular}{|c|c|}
\hline $\begin{array}{l}\text { With reference t } \\
\text { following stateme }\end{array}$ & ler mainstream / premium SB products, express your degree of a \\
\hline Perceived ouplity & I trust the quality of these products. \\
\hline remenved quantity & These products are made with good quality raw materials. \\
\hline & These products have a good quality-price ratio. \\
\hline & I often find these products on sale. \\
\hline Price advantage & The promotions I find on these products are advantageous. \\
\hline & These products are very affordable in terms of price. \\
\hline Innovation & These products provide innovative solutions. \\
\hline & The packaging of these products respects the environment. \\
\hline Sustainability & These products are eco-sustainable in reference to the raw materials used. \\
\hline Ethics & I trust the ethics of the companies that produce these products. \\
\hline
\end{tabular}

\section{Results}

To test the hypotheses, the evaluations expressed by the two groups were compared using the t-test statistic for independent samples with the SB type (mainstream vs premium) as a factor.

The means and standard deviations of the individual items are shown in Table 4.

The findings show that only the items referring to the price advantage factor receive significantly different judgments between the two groups. More precisely, the mainstream SB obtains higher judgments than the premium SB in regards to the quality-price ratio $(\mathrm{t}(567)=-3,699, \mathrm{p}<0,05)$, the frequency and the advantage of the promotions offered $(\mathrm{t}(567)=-4,153, \mathrm{p}<0,05 ; \mathrm{t}(564,313)=-3,373, \mathrm{p}<0,05)$ and the price advantage of the products $(\mathrm{t}(566,573)=-5,060, \mathrm{p}<0,05)$.

Therefore, the results of the study support hypothesis $\mathrm{H} 1$.

On the contrary, the evaluations expressed by the respondents in reference to all the other SB factors do not differ between the two groups. Specifically, there were no significant differences in regards to the evaluation of perceived quality (trust in product quality $(\mathrm{t}(567)=-0.683, \mathrm{p}=0.495)$ and use of good quality raw materials $(\mathrm{t}$ $(567)=-0.436, p=0.663)$ ); or at the level of product innovation ( $(567)=-1,575, p=0,116)$; in reference to sustainability (use of packaging that respect the environment $(\mathrm{t}(567)=-1.266, \mathrm{p}=0.206$ ) and eco-sustainable raw materials $(\mathrm{t}(567)=0.217, \mathrm{p}=0.828)$, and the ethics of the production companies $(\mathrm{t}(567)=-1,634, \mathrm{p}$ $<0,103$ ). These data do not support the hypotheses H2 (a), H2 (b), H2 (c) and H2 (d) which, therefore, must be rejected.

The findings of the present work demonstrate that only one dimension is perceived as different between the two SB segments: price advantage. According to the interviewed sample, the mainstream SB appears to be more well-known for its price advantage values than the premium one. This is due to the quality-price ratio, the 
frequency of sales promotions, the promotional advantage and, lastly, the product price.

Table 4. Means and standard deviations

\begin{tabular}{llll}
\hline Item & SB type & Mean & Standard Deviations \\
\hline \multirow{2}{*}{ I trust the quality of these products. } & Mainstream & 3.60 & 0.98 \\
& Premium & 3.55 & 1.01 \\
These products are made with good quality raw materials. & Mainstream & 3.57 & 1.01 \\
& Premium & 3.53 & 1.03 \\
These products have a good quality-price ratio. & Mainstream & 3.77 & 1.03 \\
& Premium & 3.45 & 1.07 \\
I often find these products on sale. & Mainstream & 3.65 & 1.02 \\
& Premium & 3.27 & 1.15 \\
The promotions I find for these products are advantageous. & Mainstream & 3.65 & 0.94 \\
& Premium & 3.36 & 1.09 \\
These products are very affordable in terms of price. & Mainstream & 3.73 & 0.98 \\
& Premium & 3.27 & 1.19 \\
These products provide innovative solutions. & Mainstream & 3.47 & 0.95 \\
The packaging of these products respects the environment. & Premium & 3.34 & 1.02 \\
These products are eco-sustainable in reference to the raw materials used. & Mainstream & 3.43 & 1.02 \\
& Premium & 3.45 & 1.00 \\
I trust the ethics of the companies that produce these products. & Mainstream & 3.60 & 1.00 \\
& Premium & 3.47 & 1.02 \\
\hline
\end{tabular}

\section{Discussion and Managerial Implications}

The analysis of the literature on brand equity has provided an exhaustive framework of the variables that contribute to the creation of brand identity and also highlights the importance of measuring the final consumer's expectation. In consideration of the current distribution climate, and drawing from the work of Jara and Cliquet (2012), the key distinctive SB factors from the consumer goods market were selected. This enabled us to be able to identify the important ones in terms of their ability to meet the needs of the final consumer most directly. They include: price advantage, perceived quality, innovation, sustainability and ethics. The main objective of the present work was to analyze the existence of a potential difference in the evaluations between mainstream SB shoppers and premium SB shoppers (with reference to the same retailer) in regards to the aforementioned factors.

Results show that the only dimension that differed in the evaluation was the perceived price advantage. More specifically, shoppers believed mainstream SB products to be more advantageous, with a better quality-price ratio and with more frequent and more favorable promotions in comparison to the premium segment. This result confirms, on the one hand, the role of the SB as an advantageous alternative in respect to the industrial brand and, on the other hand, the importance of price as SB choice factor (Wileman \& Jary, 1997; Burt \& Davis, 1999). However, these findings have only been confirmed for the mainstream brand, since, as expected, this factor takes on less importance for the premium one.

Despite the discrepancy in the price advantage evaluation expressed by consumers for both segments, the data demonstrate a certain uniformity of opinion in terms of the other SB choice factors. Therefore, in regards to perceived quality, the level of innovation, ethics and sustainability, there are no particular differences found between the two types of SB considered.

This phenomenon can be explained through the findings of various studies carried out in the past which have demonstrated a retailer's ability to influence the brand image of its own products (Ailawadi\&Keller, 2004; Burt\&Mavrommatis, 2006; Collins-Dodd \& Lindley, 2003; Grewal, et al., 1998; Kozinets et al., 2002; Richardson, 1997; Martín Gutiérrez, 2006).

More specifically, these findings have certain managerial implications that can be applied in order to increase SB value.

The first implication is the importance of measuring the value perceived by SB shoppers in regards to those factors that characterize the products, and which are, on the whole, communicated by the chain. In fact, without 
an up-to-date picture of their loyal consumers' reactions to an SB's positioning and reputation, it is impossible for retailers to develop the strategies necessary to increase brand equity. Given the significant synergy that exists between an SB and the retailer, the management needs to monitor the values as perceived by the consumers over time, identifying the strengths and weaknesses on which they must first intervene, in accordance with the strategy pursued and the distinctiveness of its positioning. This work must be done for each type of SB on offer in order to monitor any divergences in perception that may arise in regards to the product's key dimensions.

This action, which, as previously stated, should be carried out in a continual manner over time and must also take into account the differential that may be present between what has objectively been realized to support the SB's key factors (for example, quality, sustainability, ethics...) and the consumer's perception of them. Indeed, it is useful to understand whether there is a gap between what objectively characterizes the SB products in reference to the actions taken by the retailer and how these actions are perceived by the final demand. The greater the distance, the faster the need for the retailers to intervene by planning and implementing communication strategies to better describe to the shopper what they have already achieved. As highlighted in the literature, this potential negative gap can easily be bridged by taking actions that focus not only on the SB, but also on the overall image of the retailer.

An additional implication can be drawn from the divergence of consumer assessments in reference to distinctive SB factors at the individual segment level. Regarding the retailer analyzed herein, it seems reassuring to find only one discrepancy attributable to the concept of relative price advantage. In this context, the perception of how price advantage is more evident for mainstream SBs than for the premium ones can be explained, since the latter is, by definition, positioned in the highest offer segment. However, if differences in other distinguishing factors were found (for example, ethics), management would need to verify whether this perception, on the part of the consumer, could send the reputational dimension of the whole retailer, as well as the SB, into a deep crisis. In this scenario, the management would need to intervene, reducing this perceptual divergence through communication and branding policies.

In other words, the comparative analysis of the individual SB should, in time, become the main measurement tool, enabling the management to intervene on both the internal side - objectively improving a brand's distinctive factors through organizational and management processes - and on the external one, from and for the final consumer, putting innovative forms of communication into place with the objective of increasing trust relationships.

\section{Limitations and Future Research}

Despite the contribution made in terms of the evolution in consumer perception in relation to premium and mainstream SB segments, the present study highlights several limitations that should be pointed out and that may represent an opportunity for future research.

Firstly, the study was conducted based on a single retailer, analyzing the consumers' opinions on only two SB segments: premium and mainstream. Therefore, future research might consider a larger number of retailers in order to make a significant comparison with the objective of understanding whether different branding strategies can influence and change the shoppers' perceptions.

Secondly, only five dimensions were investigated in the present study (price advantage, perceived quality, sustainability, innovation and ethics); those found to be critical in the different SB segment evaluations and in consideration of the elements studied in the literature. In future research, it might also be useful to consider other distinctive SB factors, in an attempt to understand the incidence of potential new elements that may be of greater interest to the consumer, on account of the constant changes in the consumer's needs and sensitivities on an individual and collective level.

Thirdly, the research conducted did not refer to specific product categories, despite the fact that existing literature on SB has shown possible differences in shopper perception according to the product category and its role. For example, consumer behavior can change in regards to the role of marketing for a single category, due in part to the degree of industrial leadership and level of innovation. In future research, it could be useful to consider these differences and to understand whether the distinctive SB dimensions change in importance for the final shopper according to the role held by the product category.

Lastly, the present study did not take into consideration the possible discrepancies of the evaluation of the distinctive SB factors in relation to the store format visited by the consumer. In a market, like the Italian one, where different point of sale formats (different in their positioning and services offered) have significant market shares, it could be of particular interest to understand the consumer's perception of the SB offered, with the 
perspective of learning whether the choice behind the purchase of the SB is due more to corporate image or the chosen store format.

\section{References}

Aaker, D. A. (1996). Building strong brands. New York: The Free.

Aaker, J. L. (1997). Dimensions of brand personality. SSRN Electronic Journal. https://doi.org/10.2139/ssrn.945432

Aaker, D. A. (2004). Leveraging the corporate brand. California Management Review, 46(3), 6-18. https://doi.org/10.2307/41166218

Aaker, D. A., \& Joachimsthaler, E. (2000). The brand relationship spectrum: The key to the brand architecture challenge. California Management Review, 42(4), 8-23. https://doi.org/10.2307/41166051

Ailawadi, K. L., \& Keller, K. L. (2004). Understanding retail branding: conceptual insights and research priorities. Journal of Retailing, 80(4), 331-342. https://doi.org/10.1016/j.jretai.2004.10.008

Ambroise, L., Ferrandi, J. M., Merunka, D., \& Valette-Florence, P., (2003). Premiere application du barometre de mesure de la personnalite ' de la marque a deux enseignes franc-aises. Actes du Colloque Etienne Thil, La Rochelle.

Berry, L. (1986). Big ideas in services marketing. Journal of Consumer Marketing, 3(2), 47-51. https://doi.org/10.1108/eb008162

Berry, L. L. (2000). Cultivating service brand equity. Journal of the Academy of Marketing Science, 28(1), 128-137. https://doi.org/10.1177/0092070300

Bettman, J. R. (1974). Relationship of information-processing attitude structures to private brand purchasing behavior. Journal of Applied Psychology, 59(1), 79-83. https://doi.org/10.1037/h0035817

Blackston, M. (1992). Observations: building brand equity by managing the brand's relationships. Journal of Advertising research, 32(3), 79-83.

Bodur, H. O., Gao, T., \& Grohmann, B. (2014). The ethical attribute stigma: Understanding when ethical attributes improve consumer responses to product evaluations. Journal of Business Ethics, 122(1), 167-177. https://doi.org/10.1007/s10551-013-1764-5

Bodur, H. O., Tofighi, M., \& Grohmann, B. (2016). When should private label brands endorse ethical attributes? Journal of Retailing, 92(2), 204-217. https://doi.org/10.1016/j.jretai.2015.11.001

Burmann, C., Jost-Benz, M., \& Riley, N. (2009). Towards an identity-based brand equity model. Journal of Business Research, 62(3), 390-397. https://doi.org/10.1016/j.jbusres.2008.06.009

Burt, S., \& Davis, S. (1999). Follow my leader? Lookalike retailer brands in non-manufacturer-dominated product markets in the UK. The International Review of Retail, Distribution and Consumer Research, 9(2), 163-185. https://doi.org/10.1080/095939699342624

Burt, S. L., \& Sparks, L. (2002). Corporate branding, retailing, and retail internationalization. Corporate Reputation Review, 5(2-3), 194-212. https://doi.org/10.1057/palgrave.crr.1540174

Burt, S., \& Mavrommatis, A. (2006). The international transfer of store brand image. The International Review of Retail, Distribution and Consumer Research, 16(4), 395-413. https://doi.org/10.1080/09593960600844178

Burton, S., Lichtenstein, D. R., Netemeyer, R. G., \& Garretson, J. A. (1998). A scale for measuring attitude toward private label products and an examination of its psychological and behavioral correlates. Journal of the Academy of Marketing Science, 26(4), 293-306. https://doi.org/10.1177/0092070398264003

Busacca, B. (2000). Il valore della marca. Egea, Milano.

Christodoulides, G., De Chernatony, L., Furrer, O., Shiu, E., \& Abimbola, T. (2006). Conceptualising and measuring the equity of online brands. Journal of Marketing Management, 22(7-8), 799-825. https://doi.org/10.1362/026725706778612149

Christodoulides, G. (2010). Consumer based brand equity conceptualization and measurement: A literature review. International Journal of Market Research, 52(1), 43-66. https://doi.org/10.2501/s1470785310201053

Cobb-Walgren, C. J., Ruble, C. A., \& Donthu, N. (1995). Brand equity, brand preference, and purchase intent. 
Journal of Advertising, 24(3), 2540. https://doi.org/10.1080/00913367.1995.10673481

Coe, B. D. (1971). Private versus national preference among lower-income and middle-income consumers. Journal of Retailing, 47(3), 61-72.

Collins-Dodd, C., \& Lindley, T. (2003). Store brands and retail differentiation: the influence of store image and store brand attitude on store own brand perceptions. Journal of Retailing and Consumer Services, 10(6), 345-352. https://doi.org/10.1016/S0969-6989(02)00054-1

Cristini, G., \& Zerbini C. (2017). SBs purchase determinants in Italian market: a survey of different retailers' shoppers. International Business Research, 10(8), 1-10. https://doi.org/10.5539/ibr.v10n8p1.

Erdem, T., \& Chang, S. R. (2012). A cross-category and cross-country analysis of umbrella branding for national and store brands. Journal of the Academy of Marketing Science, 40(1), 86-101. https://doi.org/10.1007/s11747-011-0288-8

Erdem, T., \& Swait, J. (1998). Brand equity as a signaling phenomenon. Journal of Consumer Psychology, 7(2), 131-157. https://doi.org/10.1207/s15327663jcp0702_02

Grewal, D., Krishnan, R., Baker, J., \& Borin, N. (1998). The effect of store name, brand name and price discounts on consumers' evaluations and purchase intentions. Journal of Retailing, 74(3), 331-352. https://doi.org/10.1016/S0022-4359(99)80099-2

Gupta, R., \& Sen, S. (2013). The effect of evolving resource synergy beliefs on the intentions-behavior discrepancy in ethical consumption. Journal of Consumer Psychology, 23(1), 114-121. https://doi.org/10.1016/j.jcps.2012.07.004

Gupta, S., \& Kumar, V. (2013). Sustainability as corporate culture of a brand for superior performance. Journal of World Business, 48(3), 311-320. https://doi.org/10.1016/j.jwb.2012.07.015

Huang, Y., \& Huddleston, P. (2009). Retailer premium own-brands: creating customer loyalty through own-brand products advantage. International Journal of Retail \& Distribution Management, 37(11), 975-992. https://doi.org/10.1108/09590550910999389

Hoch, S. J., \& Banerji, S. (1993). When do private labels succeed? Sloan Management Review, 34(4), 57.

Hunt, S. D. (1997). Competing through relationships: Grounding relationship marketing in resource-advantage theory. Journal of Marketing Management, 13(5), 431-445. https://doi.org/10.1080/0267257X.1997.9964484

Irwin, J. R., \& Naylor, R. W. (2009). Ethical decisions and response mode compatibility: Weighting of ethical attributes in consideration sets formed by excluding versus including product alternatives. Journal of Marketing Research, 46(2), 234-246. https://doi.org/10.1509/jmkr.46.2.234

Jara, M., \& Cliquet, G. (2012). Retail brand equity: Conceptualization and measurement. Journal of Retailing and Consumer Services, 19(1), 140-149. https://doi.org/10.1016/j.jretconser.2011.11.003

Keller, K. L. (1996). Brand equity and integrated communication. Integrated Communication: Synergy of Persuasive Voices, 103-132.

Keller, K. L. (1998). Strategic brand management (Vol. 256). Upper Saddle River, NJ: Prentice Hall.

Keller, K. L. (2000). The brand report card. Harvard Business Review, 78(1), 147-158.

Keller, K. L. (2001). Building customer-based brand equity: A blueprint for creating strong brands (pp. 68-72). Cambridge, MA: Marketing Science Institute.

Keller, K. L. (1993). Conceptualizing, measuring, and managing customer-based brand equity. Journal of Marketing, 57(1), 1. https://doi.org/10.2307/1252054

Kilian, T., Walsh, G., \& Buxel, H. (2008). Measurement of attitude toward private labels: A replication and extension. In B. Swoboda, D. Morschett, T. Rudolph, P. Schnedlitz, \& H. Schramm-Klein (Eds.), European Retail Research (pp. 69-85). Wiesbaden: Gabler Verlag. https://doi.org/10.1007/978-3-8349-8099-1_4

Kozinets, R. V., Sherry, J. F., DeBerry-Spence, B., Duhachek, A., Nuttavuthisit, K., \& Storm, D. (2002). Themed flagship brand stores in the new millennium. Journal of Retailing, 78(1), 17-29. https://doi.org/10.1016/S0022-4359(01)00063-X

Laaksonen, H., \& Reynolds, J. (1994). Own brands in food retailing across Europe. Journal of Brand Management, 2(1), 37-46. https://doi.org/10.1057/bm.1994.30 
Luchs, M. G., Naylor, R. W., Irwin, J. R., \& Raghunathan, R. (2010). The sustainability liability: Potential negative effects of ethicality on product preference. Journal of Marketing, 74(5), 18-31. https://doi.org/10.1509/jmkg.74.5.18

Martín Gutiérrez, S. (2006). A model of consumer relationships with store brands, personnel and stores in Spain. The International Review of Retail, Distribution and Consumer Research, 16(4), 453-469. https://doi.org/10.1080/09593960600844285

Mizik, N., \& Jacobson, R. (2008). The financial value impact of perceptual brand attributes. Journal of Marketing Research, 45(1), 15-32. https://doi.org/10.1509/jmkr.45.1.15

Myers, J. G. (1967). Determinants of private brand attitude. Journal of Marketing Research, 4(1), 73. https://doi.org/10.2307/3150168

Narasimhan, C., \& Wilcox, R. T. (1998). Private labels and the channel relationship: A cross-category Analysis. The Journal of Business, 71(4), 573-600. https://doi.org/10.1086/209757

Nielsen (2008). Corporate ethics and fair trading: A nielsen global consumer report. Retrieved from http://pt.nielsen.com/documents/tr 200811 CSR Fairtrade global reportOctober08.pdf

Rao, A. R., \& Ruekert, R. W. (1994). Brand alliances as signals of product quality. Sloan Management Review, $36,87-87$.

Richardson, P. S. (1997). Are store brands perceived to be just another brand? Journal of Product \& Brand Management, 6(6), 388-404. https://doi.org/10.1108/10610429710190432

Rondinelli, D. A., \& Berry, M. A. (2000). Environmental citizenship in multinational corporations: social responsibility and sustainable development. European Management Journal, 18(1), 70-84. https://doi.org/10.1016/S0263-2373(99)00070-5

Sharp, B. (1996). Brand equity and market-based assets of professional service firms. Journal of Professional Services Marketing, 13(1), 3-13. https://doi.org/10.1300/j090v13n01_02

Srivastava, R. K., Shervani, T. A., \& Fahey, L. (1998). Market-based assets and shareholder value: A framework for analysis. Journal of Marketing, 62(1), 2. https://doi.org/10.2307/1251799

Srivastava, R. K., Fahey, L., \& Christensen, H. K. (2001). The resource-based view and marketing: The role of market-based assets in gaining competitive advantage. Journal of management, 27(6), 777-802. https://doi.org/10.1177/014920630102700610

Steenkamp, J.-B. E. M., \& Dekimpe, M. G. (1997). The increasing power of store brands: Building loyalty and market share. Long Range Planning, 30(6), 917-930. https://doi.org/10.1016/S0024-6301(97)00077-0

van Osselaer, S. M. J., \& Alba, J. W. (2000). Consumer learning and brand equity. Journal of Consumer Research, 27(1), 1-16. https://doi.org/10.1086/314305

Varadarajan, P. R., \& Menon, A. (1988). Cause-related marketing: A coalignment of marketing strategy and corporate philanthropy. Journal of Marketing, 52(3), 58. https://doi.org/10.2307/1251450

Verhoef, P. C., Nijssen, E. J., \& Sloot, L. M. (2002). Strategic reactions of national brand manufacturers towards private labels: An empirical study in The Netherlands. European Journal of Marketing, 36(11/12), 1309-1326. https://doi.org/10.1108/03090560210445191

Walsh, G., \& Mitchell, V. W. (2010). Consumers' intention to buy private label brands revisited. Journal of General Management, 35(3), 3-24. https://doi.org/10.1177/030630701003500302

Wileman, A., \& Jary, M. (1997). Retail power plays: From trading to brand leadership. London: Palgrave Macmillan UK. https://doi.org/10.1007/978-1-349-14378-8

Note

Note 1. Examples of this can be found in products that have specific components as organic, low fat, free from, fair trade products and so on (Kumar \& Steenkamp, 2007).

\section{Copyrights}

Copyright for this article is retained by the author(s), with first publication rights granted to the journal.

This is an open-access article distributed under the terms and conditions of the Creative Commons Attribution license (http://creativecommons.org/licenses/by/4.0/). 